\title{
Estimating the Biomass of Waterhyacinth (Eichhornia crassipes) Using the Normalized Difference Vegetation Index Derived from Simulated Landsat 5 TM
}

\author{
Wilfredo Robles, John D. Madsen and Ryan M. Wersal*
}

\begin{abstract}
Waterhyacinth is a free-floating aquatic weed that is considered a nuisance worldwide. Excessive growth of waterhyacinth limits recreational use of water bodies as well as interferes with many ecological processes. Accurate estimates of biomass are useful to assess the effectiveness of control methods to manage this aquatic weed. While large water bodies require significant labor inputs with respect to ground-truth surveys, available technology like remote sensing could be capable of providing temporal and spatial information from a target area at a much reduced cost. Studies were conducted at Lakes Columbus and Aberdeen (Mississippi) during the growing seasons of 2005 and 2006 over established populations of waterhyacinth. The objective was to estimate biomass based on nondestructive methods using the normalized difference vegetation index (NDVI) derived from Landsat 5 TM simulated data. Biomass was collected monthly using a $0.10 \mathrm{~m}^{2}$ quadrat at 25 randomly-located locations at each site. Morphometric plant parameters were also collected to enhance the use of NDVI for biomass estimation. Reflectance measurements using a hyperspectral sensor were taken every month at each site during biomass collection. These spectral signatures were then transformed into a Landsat 5 TM simulated data set using MatLab ${ }^{\circledR}$ software. A positive linear relationship $\left(r^{2}=0.28\right)$ was found between measured biomass of waterhyacinth and NDVI values from the simulated dataset. While this relationship appears weak, the addition of morphological parameters such as leaf area index (LAI) and leaf length enhanced the relationship yielding an $\mathrm{r}^{2}=0.66$. Empirically, NDVI saturates at high LAI, which may limit its use to estimate the biomass in very dense vegetation. Further studies using NDVI calculated from narrower spectral bands than those contained in Landsat 5 TM are recommended.
\end{abstract}

Nomenclature: Waterhyacinth, Eichhornia crassipes (Mart.) Solms EICCR.

Key words: Remote sensing, Landsat 5 TM, nondestructive sampling methods, hyperspectral reflectance.

Waterhyacinth [Eichhornia crassipes (Mart.) Solms] is a nuisance, free-floating aquatic weed that causes economic losses and negatively impacts aquatic environments

DOI: 10.1614 /IPSM-D-14-00033.1

* Graduate Student, Associate Extension/Research Professor, and Research Associate, Geosystems Research Institute, Box 9652, Mississippi State, MS 39762. Current address of first author: Assistant Professor, Department of Crops and Agro-Environmental Science, University of Puerto Rico, Mayagüez, Box 9000, Mayagüez, PR 00681. Current address of second author: USDA-ARS, EIWRU, Univ. of California-Davis, Dept. of Plant Sciences, Mail Stop 4, Davis, CA 95616. Current address of third author: Lonza - Water Technology, Alpharetta Innovation and Technology Center, 1200 Bluegrass Lakes Pkwy, Alpharetta, GA 30004. Corresponding author's E-mail: wilfredo.robles2@upr.edu worldwide (Holm et al. 1991). In south Alabama, excessive growth of waterhyacinth is reported to limit the production of phytoplankton through competition for light which consequently reduces fish production ( $\mathrm{McVea}$ and Boyd 1975). Likewise, water use for recreation, power generation, and consumption are also limited due to the presence of waterhyacinth (Rushing 1974). For these reasons waterhyacinth is considered one of the "world's worst weeds" (Holm et al. 1991).

Typically, the biomass of waterhyacinth is estimated using quadrats with a specific unit area placed over the plant mat. Using this method, Center and Spencer (1981) and Knipling et al. (1970) found that waterhyacinth biomass ranged from 2.3 and $2.5 \mathrm{~kg} \mathrm{DW} \mathrm{m}{ }^{-2}$. The problem with this quantitative approach is that it is (1) it is labor and time intensive to collect and process samples and (2) it is 


\section{Management Implications}

Typically, the biomass of waterhyacinth is estimated using quadrats with a specific unit area placed over the plant mat. However, it is labor and time intensive to collect and process samples. Moreover, this method is destructive because it removes plant material from the system which affects long term studies of plant growth. The normalized difference vegetation index (NDVI) is a well-known vegetation index that can be used to monitor aquatic plants. However, limitations due canopy complexity during the growing season often limit its use. Based on the results, NDVI alone is not sufficient to estimate the biomass of waterhyacinth. The poor predictive performance of band 4, as well as canopy complexity related to waterhyacinth phenology during the growing season and vegetation cover/water background ratio likely affected the performance of NDVI. According to this study, measuring morphometric parameters such as leaf area index may enhance the performance of NDVI derived from Landsat 5 TM or other multispectral sensors with same spectral resolution. Therefore, the sole use of NDVI from Landsat $5 \mathrm{TM}$ is not recommended to estimate the biomass of waterhyacinth. It is suggested that large-scale waterhyacinth management would consider NDVI derived from other multispectral sensors (e.g. Landsat 8 OLI). Current results could be useful to test new multispectral or hyperspectral sensors for aquatic vegetation management.

a destructive method that removes plant material from the system which may be problematic for longer term studies of plant growth.

Alternately, nondestructive methods have been developed to estimate the biomass of emergent aquatic plants based on morphometric parameters such as plant height and leaf area (Daoust and Childers 1998; Gouraud et al. 2008; Spencer et al. 2006; Thursby et al. 2002). Submersed, floating-leaved and free-floating aquatic plants such as Eurasian watermilfoil (Myriophyllum spicatum L.), American pondweed (Potamogeton nodosus Poir.), and waterhyacinth have been studied using nondestructive methods (Center and Spencer 1981; Pine et al. 1989). Nondestructive approaches produce comparable data to destructive methods and typically require less time and effort while maintaining adequate accuracy (Daoust and Childers 1998; Thursby et al. 2002). Likewise, speciesspecific regression equations developed using nondestructive methods has the potential to be extended to other locations where the species is growing and suggested to be combined with remote sensing data to estimate its biomass (Daoust and Childers 1998; Spencer et al. 2006). Moreover, the combination of nondestructive methods and remote sensing allows for spatial monitoring of aquatic plants across larger geographic areas (Lehmann and Lachavanne 1997).

Remote sensing collects information from vegetation by measuring light reflectance at different wavelengths from the target to produce imagery. Useful information may be extracted from images with the creation of image products based on vegetation indices. Many vegetation indices have been developed, but the normalized difference vegetation index (NDVI) has been one of the most extensively studied and used (Jensen 2000). The NDVI is a dimensionless index developed in the 1970s that estimates photosynthetic active biomass (Rouse et al. 1973; Tucker 1979) based on the difference and sum of reflectance in the spectral regions (or hereafter spectral bands) of red and near-infrared (NIR). The principle of NDVI is based on the reflectance and absorption of these spectral bands by chlorophyll and internal leaf cells (e. g. spongy mesophyll) depending on plant health (Jensen 2000). It is reported that ground collected biomass of the African savannas correlates significantly to NDVI values from NOAA satellites (Tucker et al. 1985). Similarly vegetation biomass of shrublands, grasslands and salt water marshes in California, US can be estimated using NDVI collected from handheld spectroradiometer (Gamon et al. 1995; Zhang et al. 1997). Besides plant biomass estimation, NDVI has been used to detect herbicide injury (Henry et al. 2004, Robles et al. 2010), estimate variations of photosynthetic activity with respect to atmospheric $\mathrm{CO}_{2}$ levels (Tucker et al. 1986; Tucker and Sellers 1986), differentiate aquatic plant species (Peñuelas et al. 1993; Underwood et al. 2006), and estimate plant pigment concentrations and leaf area index (Green et al. 1997; Peñuelas et al. 1997). The majority of published studies that have used NDVI to estimate biomass have examined either terrestrial or emergent aquatic plants suggesting further investigation of other aquatic plant growth forms like free-floating aquatic plants. Often the use of remote sensing is limited in aquatic habitats due to high absorption by water, canopy exposure (Jensen 2000) as well as water turbidity (Underwood et al. 2006). In fact, recent studies documented that the use of remote sensing is more accurate on emergent and floating aquatic vegetation mapping than submersed aquatic vegetation (Underwood et al. 2006; Vis et al. 2003).

Many studies have explored the use of NDVI at small scales using handheld spectroradiometers (Gamon et al. 1995; Henry et al. 2004; Zhang et al. 1997). The present study used a handheld hyperspectral sensor to collect spectral data over waterhyacinth and simulate the NDVI of Landsat 5 TM multispectral sensor data. The thematic mapper (TM) sensor onboard Landsat 5 is the oldest currently inoperable sensor that have provided multispectral imagery since 1984 (USGS 2013b). Landsat 5 TM has produced multispectral imagery in 7 spectral bands including the visible and infrared regions. Such bands have been useful in detecting herbicide phytotoxicity on waterhyacinth (Robles et al. 2010). Many multispectral images have been archived and are available for use to monitor long-term vegetation changes (Xie et al. 2008). The TM sensor has also been used to develop vegetation indices and estimate the biomass of marsh aquatic 
Table 1. Comparison of Thematic Mapper (TM) and Landsat 8 Operational Land Imager (OLI) spectral band ranges (nanometers) (USGS 2013b). All spectral bands have a spatial resolution of $30 \mathrm{~m}$. Bold type indicates spectral bands that are widely recommended for vegetation monitoring. Note that Landsat 8 OLI has two more spectral bands than Landsat 5 TM.

\begin{tabular}{|c|c|c|c|}
\hline \multicolumn{2}{|c|}{ Landsat 5 TM } & \multicolumn{2}{|c|}{ Landsat 8 OLI } \\
\hline 1 (blue) & $450-520$ & 1 (coastal aerosol) & $430-450$ \\
\hline 2 (green) & $520-600$ & 2 (blue) & $450-510$ \\
\hline 3 (red) & $630-690$ & 3 (green) & $530-590$ \\
\hline 4 (near-infrared) & 760-900 & 4 (red) & $640-670$ \\
\hline \multirow[t]{3}{*}{7 (midinfrared) } & $2,080-2,350$ & 7 (shortwave IR) & $2,110-2,290$ \\
\hline & & 8 (panchromatic) & 500-680 \\
\hline & & 9 (cirrus) & $1,360-1,380$ \\
\hline
\end{tabular}

vegetation (Zhang et al. 1997). Moreover Landsat 5 TM imagery has been used to document the distribution and extent of waterhyacinth in Lake Victoria, Africa over a twelve-year period (Albright et al. 2004).

The objective is to evaluate remote sensing using NDVI derived from simulated Landsat 5 TM sensor data alone and in combination with morphometric parameters to estimate waterhyacinth biomass. The goals are to document the effective use of remote sensing as a management tool for rapidly assessing production of waterhyacinth across large areas, and to develop specific strategies to enhance the use of NDVI estimations. This experiment used simulated spectral data from Landsat 5 TM because the TM sensor has provided continuous imagery (every $16 \mathrm{~d}$ ) of the earth's surface since 1984 until 2011. Although Landsat 5 TM is currently inoperable, its spectral and spatial resolution is similar to current sensors like Landsat 7 ETM (USGS 2013b). Moreover, new sensors such as Landsat 8 OLI have narrower spectral bands within the same spectral range of Landsat 5 TM (Table 1). Knowing this information, imagery comparison would be possible when considering the aforementioned sensors (USGS 2013a). This study is not intended to compare Landsat 5 TM with other sensors, but to show that its utility persists even though it is currently inoperable.

\section{Materials and Methods}

Study Site. Studies were conducted in Lake Columbus and Lake Aberdeen, both located in northeastern Mississippi. Lake Columbus, $(1,208$ ha in area [2,984 ac]) is located in Lowndes and Clay Counties and Lake Aberdeen, (967 ha in area [2,388 ac]) is located in Monroe County. Both lakes are impounded sections of the Tennessee Tombigbee Waterway and facilitate commercial transportation between the Gulf of Mexico and the Tennessee River
(Auerbach et al. 1985, Green 1985), and also for recreation (e.g., fishing) and wildlife habitat (Green 1985).

Biomass Sampling and Morphometric Parameters Measurements. The biomass of established monospecific populations of waterhyacinth were sampled from May 2005 to November 2006 at two sites in Lake Columbus (Site 1: $33^{\circ} 35^{\prime} 8^{\prime \prime} \mathrm{N}, 88^{\circ} 28^{\prime} 58^{\prime \prime} \mathrm{W}$; Site $2: 33^{\circ} 34^{\prime} 51^{\prime \prime} \mathrm{N}, 88^{\circ} 29^{\prime} 3^{\prime \prime} \mathrm{W}$ ) and one site in Lake Aberdeen $\left(88^{\circ} 31^{\prime} 33^{\prime \prime} \mathrm{N}, 33^{\circ} 50^{\prime} 43^{\prime \prime}\right)$. All three sites maintained water $\mathrm{pH}$ of $7.0( \pm 0.3)$, and a maximum specific conductance of $0.3 \mathrm{~ms} / \mathrm{cm}$. During sampling months, water temperature ranged from 10 to 32 C (50 to 90 F). Between December 2005 and March 2006, biomass was not collected due to low air temperatures $(<6 \mathrm{C})$ that caused above-water biomass of waterhyacinth to die leaving just stembases and root tissues (Owens and Madsen 1995). The two sites at Lake Columbus were $530 \mathrm{~m}(1,166 \mathrm{ft})$ apart. All three sites were a cove of vegetation off of the main river channel and were 0.25 ha in size. The waterhyacinth mat was covering the entire water surface. Within each site, only waterhyacinth plants growing in full sunlight were sampled, avoiding the ones growing along the shoreline or under tree canopies. Biomass was sampled every month using a polyvinyl chloride (PVC) quadrat of $0.10 \mathrm{~m}^{2}$ in size, randomly placed 25 times over plant canopy (Madsen 1993a). Morphometric parameters were obtained at each sampling date.

The morphometric parameters measured were: leaf blade area (length by width), leaf length from base of petiole to leaf tip and number of leaves per plant. Each measurement was made from one plant randomly selected from each quadrat sample. Leaf length and blade area were measured from the first unfolded leaf of the randomly selected plant. Samples were then collected manually, placed in plastic bags, transported to the laboratory, and sorted into 
different plant structures such as inflorescence, roots, stem bases, stolons, and leaves. Plant samples were dried in a forced-air oven at $70 \mathrm{C}$ for $72 \mathrm{hr}$ and weighed. For analysis purposes, shoot biomass was composed of everything above the water surface which included inflorescence, leaves and stolons; whereas root biomass included stem bases (rhizome) and roots. Total biomass was the combination of all plant tissues.

Spectral Response Data Collection. Spectral data were obtained monthly from each site using a handheld hyperspectral sensor (ASD Spectroradiometer, Field Spec Pro ${ }^{\circledR}$ model FR. Analytical Spectral Devices, Inc. 5335 Sterling Drive, Boulder, CO, USA). This sensor measured reflectance in 2151 spectral bands ranging between $350 \mathrm{~nm}$ and $2500 \mathrm{~nm}$ with a $1.4 \mathrm{~nm}$ bandwidth at a field of view (FOV) of $25^{\circ}$. During each sampling event, a total of 25 hyperspectral signatures were collected randomly at $15 \mathrm{~cm}$ intervals across the mat using the bare fiber of the sensor. The sensor was held at nadir at $0.3 \mathrm{~m}$ over the plant canopy, obtaining hyperspectral signatures from an area of $137 \mathrm{~cm}^{2}$ (21.2 in. ${ }^{2}$ ) for each interval. All hyperspectral data was collected at noon $( \pm 1 \mathrm{~h})$ on cloudless days using sunlight as the energy source.

Landsat 5 TM Data Simulation. Monthly hyperspectral signatures for each site were transformed to simulate the Landsat 5 TM multispectral sensor data set. The transformation was performed using a mathematical model developed in MatLab software (MatLab, version 7.4. The Mathworks Inc. Natick, MA, USA). The model when applied created a spectral filter to the hyperspectral data set reducing the number of bands into bands number $1,2,3$, 4, 5, and 7 of Landsat 5 TM. A transformation matrix was constructed with each column containing weights of the spectral filters in an orthogonal manner to create a relative spectral response for each spectral band (NASA 2008). The thermal band (band 6) was not extracted because its use is more related to temperature emitted by a surface area. The shorter wavelengths band 1 and 2 were also not considered in the analysis due to atmospheric attenuation which may affect their use in plant applications. Therefore, only spectral bands 3, 4, 5, and 7 were considered in the analysis. The simulated multispectral data set of those spectral bands contained pixel intensity values for each band in a range of 0 to 255 , corresponding to the radiometric resolution (8-bit) of Landsat 5 TM.

Data Analysis. Leaf blade area was used to calculate leaf area index (LAI) of waterhyacinth. The LAI was calculated as it can be directly correlated to spectral response changes of a plant canopy (Curran and Milton 1983; Gamon et al. 1995; Hunt et al. 2007; Law and Waring 1994). Hence, LAI was calculated as (Adapted from Center and Spencer 1981):

$$
\mathrm{LAI}=(\mathrm{LBA} \times \mathrm{LPP} \times \mathrm{NP})
$$

where LBA $=$ leaf blade area $\left(\mathrm{m}^{2}\right) ; \mathrm{LPP}=$ leaves per plant, and $\mathrm{NP}=$ number of plants per $\mathrm{m}^{2}$.

All statistical analyses were performed in SAS (SAS, version 9.1. SAS Institute Inc. Cary, NC, USA) at a significance level of 0.05 . Data from each site was combined into one dataset according to each response variable measured. Additionally, the vegetation index NDVI was added to the dataset and calculated from the simulated spectral bands 3 and 4 of Landsat 5 TM using the following ratio:

$$
\mathrm{NDVI}=(\mathrm{B} 4-\mathrm{B} 3) /(\mathrm{B} 4+\mathrm{B} 3)
$$

where B3 = simulated pixel value of band 3 (630 to 690 $\mathrm{nm}$ ), and $\mathrm{B} 4=$ simulated pixel value of band 4 (760 to $900 \mathrm{~nm}$ ).

Monthly mean biomass, NDVI and each spectral band response (pixel value) were obtained for each site using PROC MEANS. Biomass and calculated NDVI means for each site were plotted against time to assess temporal changes. A correlation procedure (PROC CORR) was used to determine if a relationship exists between spectral bands 3, 4, 5, 7, NDVI and shoot, root and total biomass. Yielded Spearman's correlation coefficients $(r)$ obtained were used to explore further the potential use of individual bands to develop new indices and if the relationship between NDVI and biomass could be affected by spectral band 3 or 4 individually.

Means of each site were pooled across year to determine the relationship between biomass and NDVI. A linear and polynomial regression analysis was performed using PROC GLM and only the highest and consistent coefficients of determination $\left(r^{2}\right)$ with their corresponding regression equations were used. Similarly, regression analysis was used to determine relationships between LAI and NDVI. Data of plant morphology measured in the plant canopy like leaf length, blade area, and number of leaves were added into a nonlinear regression model to find the most appropriate model that best described the relationship between biomass and NDVI. Models were compared based on their respective adjusted $r^{2}$, and the best fitting model was the statistically significant model with the highest adjusted $r^{2}$.

\section{Results and Discussion}

Relationship Between Spectral Band Response, NDVI and Biomass. Harvested biomass in both sites on Lake Columbus was generally lower in comparison to Lake Aberdeen. However, all three sites follow the same trend where values of both biomass and NDVI were low during spring months (April and May), and rapidly increased after June (Figure 1). Between the months of July and 


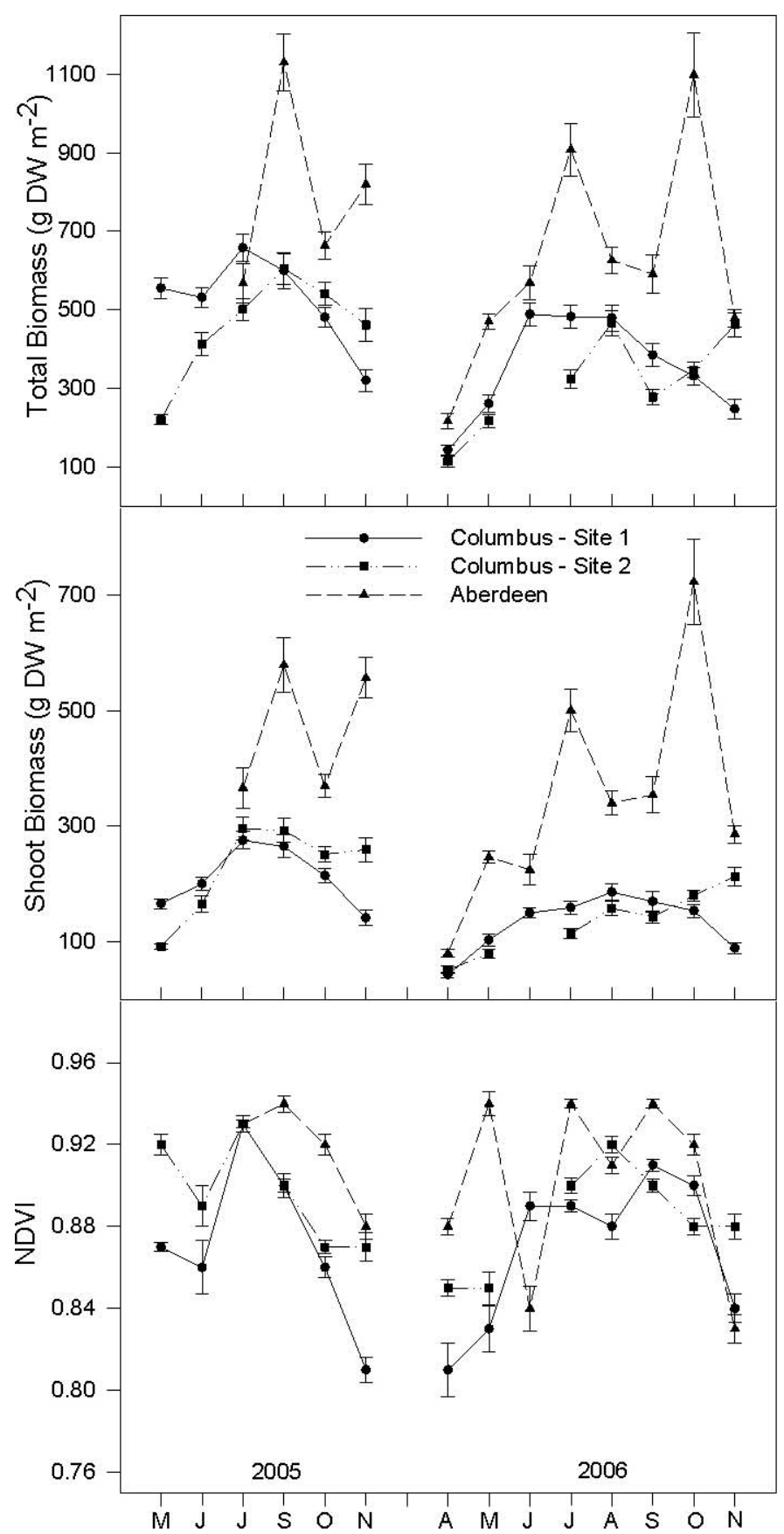

Figure 1. Temporal changes of biomass and NDVI for each sampling site. Values represent means $\pm 1 \mathrm{SE}$ for each sampling date.

September, both variables reached their maximum and eventually declined after October. Monthly changes of biomass obtained in this study follow the seasonality of waterhyacinth (Center and Spencer 1981).

The band 3 was the only spectral band significantly correlated to total and shoot biomass of waterhyacinth yielding a correlation coefficient $(r)$ of -0.38 and -0.45 respectively (Table 2 ). The relationship is linear and
Table 2. Correlation between simulated spectral bands and NDVI from Landsat $5 \mathrm{TM}$ and the biomass of waterhyacinth. Values are presented as Pearson's correlation coefficient (r) for each variables relationship. Biomass is represented as total (shoot and root combined), shoot, and root.

\begin{tabular}{llllll}
\hline & \multicolumn{4}{c}{ Spectral bands of Landsat 5 TM } & \\
\cline { 2 - 4 } Biomass & Band 3 & Band 4 & Band 5 & Band 7 & NDVI \\
\hline Total & $-0.38^{*}$ & 0.17 & -0.03 & -0.22 & $0.53^{*}$ \\
Shoot & $-0.45^{*}$ & 0.10 & -0.07 & -0.20 & $0.52^{*}$ \\
Root & -0.16 & 0.25 & 0.05 & -0.20 & $0.42^{*}$ \\
\hline
\end{tabular}

* significant correlation at $\mathrm{p}<0.05$. Band $3(630-690 \mathrm{~nm})$; Band 4 (760-900 nm); Band 5 (1,550-1,750); Band 7 (2,0802,350 $\mathrm{nm})$.

negative which means that as biomass increased, values of band 3 decreased. The same trend was reported by Todd et al. (1998) and Tucker (1979) with the red band of Landsat on terrestrial plants. Such relationships are based on the amount of photosynthetic tissue in the plant mat which relates directly to biomass (Jensen 2000; Tucker and Sellers 1986). Specifically, as the amount of chlorophyll molecules increases, reflectance or pixel values will decrease (Carter 1993; Carter and Knapp 2001). Band 4 alone was not significantly correlated to biomass. In contrast, other studies reported that near-infrared values increased with increases in biomass (Tucker 1979; Valta-Hulkkonen et al. 2004). Although it is not clear why band 4 was not significantly correlated to biomass in our study, the relationship between NDVI and biomass (including total, shoots, and roots) is significant regardless of band 4 (Table 2). Regression analysis showed that the relationship between NDVI and biomass is linear and positive, where as NDVI increased, the biomass of waterhyacinth also increased (Figure 2). Both total and shoot biomass yielded the highest $r^{2}$ in comparison with root biomass indicating that NDVI is a poor estimator of root biomass. The poor performance of NDVI in estimating root biomass is due to the fact that the spectral response is influenced by plant canopy or photosynthetic tissue exposed from the water (Peñuelas et al. 1993). That means that only shoot biomass which is the photosynthetic active tissue can be monitored with NDVI.

Although all three relationships between biomass (shoot, root, and total) of waterhyacinth and NDVI appear to be significant, only $28 \%$ of the total variation can be explained depending on plant structure (Figure 2), suggesting that the use of NDVI alone is insufficient in estimating waterhyacinth total biomass. It is suggested that the use of NDVI to estimate the biomass of floating aquatic species like waterhyacinth may be limited to the lack of performance of band 4 (Table 2), canopy complexity (Tucker and Sellers 1986) which varies during the growing 


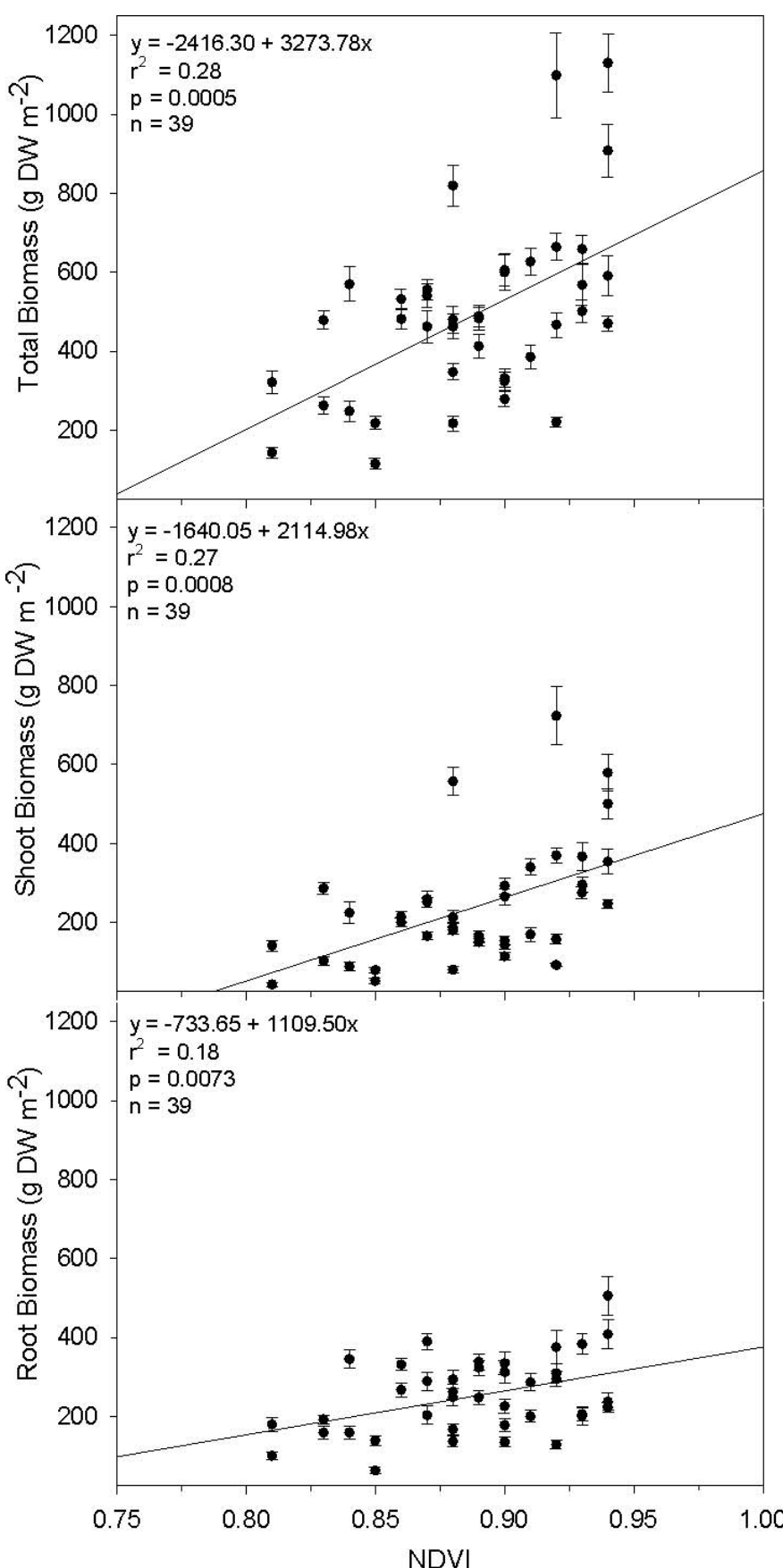

Figure 2. Linear relationship between NDVI values and waterhyacinth biomass. Values represent means \pm 1 SE for each site and sampling date.

season (Madsen 1993b; Rouse et al. 1973), as well as vegetation cover/water background ratio (Best et al. 1981; Peñuelas et al. 1993). In fact, recent studies suggest that natural populations of waterhyacinth are better monitored when biomass have peaked during the season (Hestir et al. 2008). Canopy complexity in terms of leaf orientation changes from a predominantly horizontal position to one that is vertical due to intraspecific competition as the

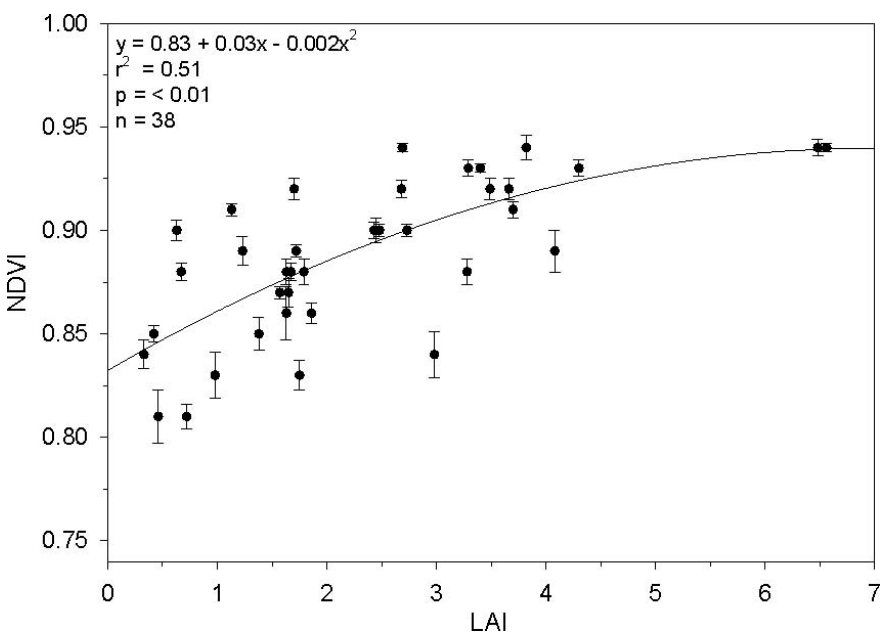

Figure 3. Relationship between NDVI values and leaf area index (LAI) of waterhyacinth. Values represent means \pm 1 SE for each site and sampling date.

growing season progresses (Madsen 1993b). Similarly, waterhyacinth growth is less dense early in the growing season, and the associated gaps in the plant canopy result in increased absorption in band 4. If the plant canopy is not covering the water surface, estimation of plant biomass using NDVI may be poor (Peñuelas et al. 1993).

NDVI and Morphometric Parameters as Biomass Estimators. The relationship between LAI and NDVI was quadratic (Figure 3), indicating that NDVI tended to saturate at higher values of LAI from waterhyacinth. This means that NDVI values will not continue to increase at LAI values higher than 2 . Other studies conducted in mangroves showed that the relationship between LAI and NDVI was linear, yielding an $\mathrm{r}^{2}$ of 0.74 (Green et al. 1997). However, published studies report that NDVI is not sensitive to dense canopies of terrestrial plants (Mutanga and Skidmore 2004), specifically those with LAI of more than 2 (Gamon et al. 1995; Law and Waring 1994).

Therefore, it may be necessary to use other parameters to improve biomass estimation in combination with the use of NDVI for floating aquatic plants like waterhyacinth. Morphometric parameters such as leaf length, leaves per plant, and LAI were added to the regression model to improve biomass estimation (Tables 3 and 4). The estimation of total and aboveground biomass of waterhyacinth was improved $\left(r^{2}=0.70,0.66\right.$ respectively) when LAI was combined with either NDVI or leaf length. Similarly, the combination of leaf length with number of leaves per plant also yielded $r^{2}$ values higher than those obtained with the use of NDVI alone. Previously, the combination of leaf length and number of leaves has been used to estimate biomass of individual plants of waterhyacinth in the state of Florida, USA (Center and Spencer 1981). Similarly, a high correlation 
Table 3. The three highest coefficients of determination $\left(\mathrm{r}^{2}\right)$ for each combination of response variables used to estimate the total biomass of waterhyacinth. I = NDVI, LL = leaf length $(\mathrm{m})$, LPP = leaves per plant, LAI = leaf area index, B = biomass of waterhyacinth $\left(\mathrm{g} \mathrm{DW} \mathrm{m}^{-2}\right)$.

\begin{tabular}{lcccc}
\hline Variables & Adj. $r^{2}$ & $r^{2}$ & P value & \multicolumn{1}{c}{ Equation* } \\
\hline LL*LAI & 0.64 & 0.66 & $<0.01$ & $\mathrm{~B}=145.2+6.0 \mathrm{LL}+78.0 \mathrm{LAI}$ \\
I*LL $^{*}$ LAI & 0.63 & 0.66 & $<0.01$ & $\mathrm{~B}=236.0-107.3 \mathrm{I}+6.1 \mathrm{LL}+80.0 \mathrm{LAI}$ \\
LL & 0.62 & 0.64 & $<0.01$ & $\mathrm{~B}=-424.2+14.1 \mathrm{LL}+79.3 \mathrm{LPP}$ \\
\hline
\end{tabular}

${ }^{*}$ Linear regression equation is based on mean monthly values from all three sites, $\mathrm{N}=39$.

was also obtained when leaf length was included in the model to estimate the biomass of emergent aquatic plants like arrowhead (Sagittaria lancifolia L.) (Daoust and Childers 1998).

Based on these results, NDVI derived from Landsat $5 \mathrm{TM}$ alone is not adequate to estimate biomass of waterhyacinth, and should be combined with measurements of LAI and/or leaf length. Although the literature suggests that NDVI is a good estimator of plant biomass, particularly in terrestrial habitats, the reality is that its use may not apply to all species, or in aquatic habitats as was shown in this study and other parameters are needed to increase the accuracy of biomass estimations.

\section{Further Research}

Besides observed limitations of NDVI derived from Landsat $5 \mathrm{TM}$ to estimate waterhyacinth biomass, it is suggested that results may also be limited to its spectral band range. Typically, studies derive NDVI from many available multispectral sensors on-board satellites with different spectral band ranges. For instance, studies conducted by Peñuelas et al. (1993) report that NDVI is adequate to estimate the biomass of aquatic plant species. However, those studies used NDVI derived from the weather satellite, NOAA-AVHRR, which has a wider NIR band than Landsat $5 \mathrm{TM}$ ranging from 725 to $1100 \mathrm{~nm}$. Others have reported that NDVI derived from Landsat $5 \mathrm{TM}$ is not the best vegetation index to estimate salt marsh vegetation biomass but suggest other vegetation indices derived from the same sensor to achieve this goal (Zhang et al. 1997).
Further improvements could be obtained by using or including other spectral ranges when developing the index. For instance, Tucker (1977) suggested that the spectral region from 740 to $1,000 \mathrm{~nm}$ was feasible to estimate biomass. Specifically, waterhyacinth can be better distinguished from other aquatic vegetation within 700 and 1,200 nm (Underwood et al. 2006). Others have suggested that the red edge (706 to $755 \mathrm{~nm}$ ) contains most of the information to estimate biomass when plant canopy density is high (Mutanga and Skidmore 2004). Therefore, there are other spectral regions that should be considered. Following this concept, monthly averaged hyperspectral signatures of waterhyacinth are shown in Figure 4 (A-C), in which spectral band ranges used in this study are shown along with potential spectral areas that can be used to derive NDVI. Notice that the red edge (Figure $4 \mathrm{~B}$ ) and longer wavelengths on the infrared region (Figure 4C) were not studied because they were not contained in the spectral bands of Landsat 5 TM. The spectral response of these bands changes temporally, suggesting they may be useful for biomass estimation. Based on the results of this study, the exploration of the performance of NDVI using narrower bands (e.g., 30 $\mathrm{nm}$ increments or less) to estimate the biomass of waterhyacinth could potentially be used to improve the performance of NDVI. Newly launched multispectral sensors like Landsat 8 OLI have narrower red and infrared bands (Table 1) that could extend the use of archived images from Landsat 5 TM. On the other hand, narrower spectral bands explored with the current dataset (Figure 4) may help to interpret hyperspectral sensor data used on plant applications (Hestir et al. 2008; Underwood et al. 2006).

Table 4. The three highest coefficients of determination $\left(r^{2}\right)$ for each combination of response variables used to estimate the aboveground biomass of waterhyacinth. I = NDVI, LL = leaf length $(\mathrm{m}), \mathrm{LPP}=$ leaves per plant, LAI $=$ leaf area index, B = biomass of waterhyacinth $\left(\mathrm{g} \mathrm{DW} \mathrm{m}^{-2}\right)$.

\begin{tabular}{lcccc}
\hline Variables & Adj. $r^{2}$ & $r^{2}$ & P value & Equation* \\
\hline LL*LAI & 0.68 & 0.70 & $<0.01$ & $\mathrm{~B}=-4.5+6.6 \mathrm{LL}+30.0 \mathrm{LAI}$ \\
I LL*LAI $^{*}$ LL $^{*}$ PP & 0.67 & 0.70 & $<0.01$ & $\mathrm{~B}=88.0-109.3 \mathrm{I}+6.6 \mathrm{LL}+31.6 \mathrm{LAI}$ \\
\hline
\end{tabular}

* Linear regression equation is based on mean monthly values from all three sites, $\mathrm{N}=39$. 


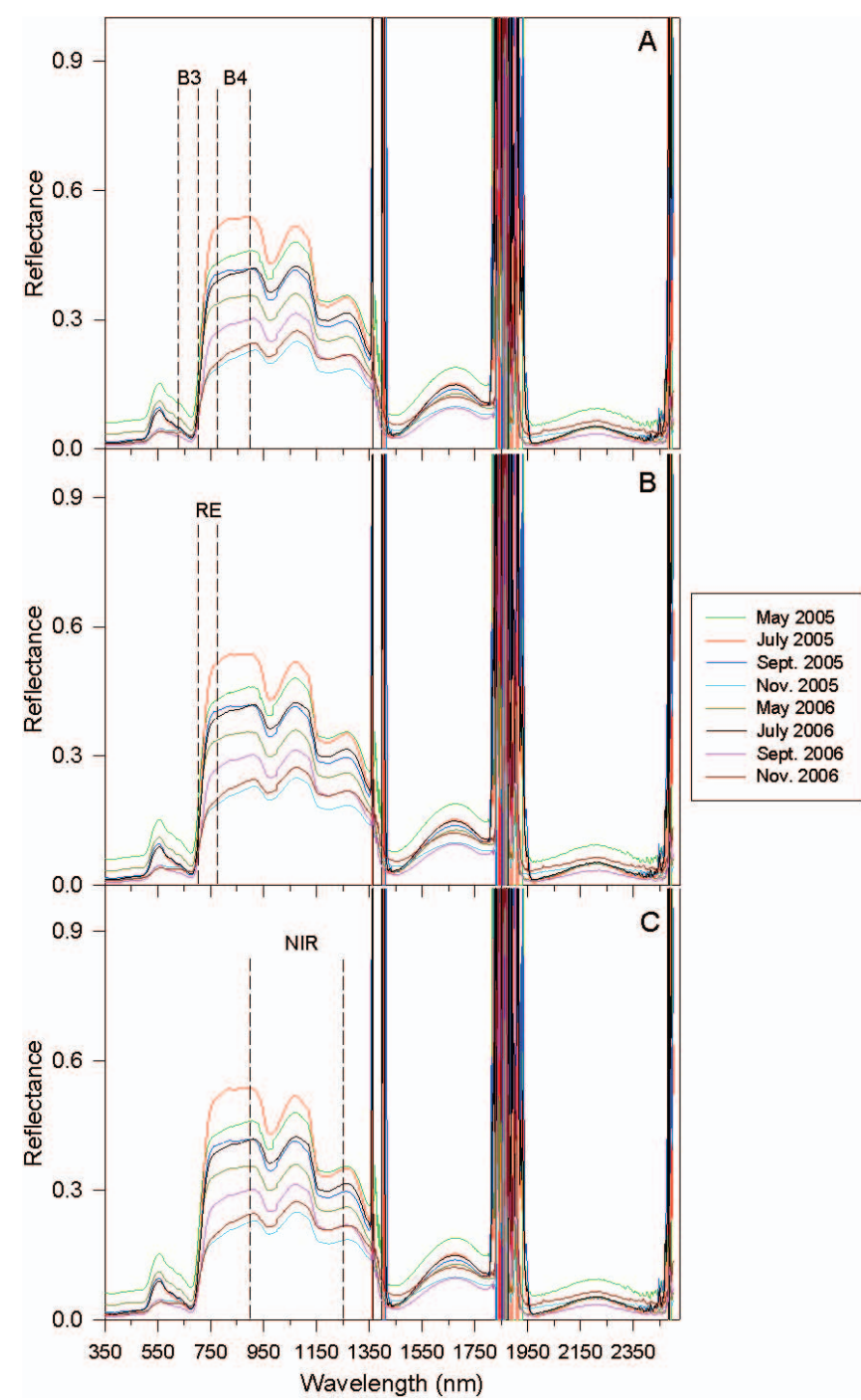

Figure 4. Monthly average hyperspectral signatures of waterhyacinth. (A) Represents spectral band range of band 3 (B3) and band 4 (B4) of Landsat 5 TM. (B and C) is the suggested spectral range for consideration which includes the red edge (RE) and near-infrared (NIR).

\section{Acknowledgments}

The authors would like to thank Dr. Lori M. Bruce and Mr. Terrance West of the Department of Electrical and Computer Engineering for developing the Matlab Code used on this study. Funding source provided by U.S. Geological Survey under Award Number 08HQAG013908121105, Invasive Species Program. Internal reviews were provided by Drs. Lori Bruce, John Byrd, Gary Ervin, and David Shaw. This manuscript has been approved for publication as Journal Article No. J-11668 of the Misssissippi Agricultural and Forestry Experiment Station, Mississippi State University.

\section{Literature Cited}

Albright TP, Moorhouse TG, McNabb TJ (2004) The rise and fall of waterhyacinth in Lake Victoria and the Kagera River Basin, 19892001. J Aquat Plant Manage 42:73-84

Auerbach SI, LaMoreaux PE, McLindon GJ (1985) The TennesseeTombigbee Waterway: An example of synergistic science and engineering. Environ Geol 7:3-8

Best RG, Wehde ME, Linder RL (1981) Spectral reflectance of hydrophytes. Remote Sens Environ 11:27-35

Carter GA (1993) Responses of leaf spectral reflectance to plant stress. Am J Bot 80:239-243

Carter G A and A K Knapp (2001) Leaf optical properties in higher plants: linking spectral characteristics to stress and chlorophyll concentration. Am J Bot 88:677-684

Center TD, Spencer NR (1981). The phenology and growth of waterhyacinth [Eichhornia crassipes (Mart.) Solms] in a eutrophic north-central Florida lake. Aquat Bot 10:1-32

Curran PJ, Milton EJ (1983) The relationship between the chlorophyll concentration, LAI and reflectance of a simple vegetation canopy. Int J Remote Sens 4:247-255

Daoust RJ, Childers DL (1998) Quantifying aboveground biomass and estimating net above primary production for wetland macrophytes using a non-destructive phenometric technique. Aquat Bot 62: $115-133$

Gamon JA, Field CB, Goulden ML, Griffin KL, Hartley AE, Joel G, Peñuelas J, Valentini R (1995) Relationships between NDVI, canopy structure, and photosynthesis in three Californian vegetation types. Ecol Appl 5:28-41

Gouraud C, Giroux J, Mesléard F, Desnouhes L (2008) Non-destructive sampling of Schoenoplectus maritimus in southern France. Wetlands 28:532-537

Green SR (1985) An overview of the Tennessee-Tombigbee Waterway. Environ Geol 7:9-13

Green EP, Mumby PJ, Edwards AJ, Clark CD, Ellis AC (1997) Estimating leaf area index of mangroves from satellite data. Aquat Bot 58:11-19

Henry WB, Shaw DR, Reddy KR, Bruce LM, Tamhankar HD (2004) Remote sensing to detect herbicide drift on crops. Weed Technol 18: 358-368

Hestir EL, Khanna S, Andrew ME, Santos MJ, Viers JH, Greenberg JA, Rajapakse SS, Ustin SL (2008) Identification of invasive vegetation using hyperspectral remote sensing in the California Delta ecosystem. Remote Sens Environ 112:4034-4047

Holm LG, Plucknett DL, Pancho JV, Herberger JP (1991) The world's worst weeds; Distribution and biology. Malabar, FL: Krieger Publishing Company. 609 p

Hunt ER Jr., Daughtry CST, Kim MS, Williams AEP (2007) Using canopy reflectance models and spectral angles to assess potential of remote sensing to detect invasive weeds. J Appl Remote Sens 1:1-19

Jensen JR (2000) Remote sensing of the environment: an earth resource perspective. Upper Saddle River, NJ: Prentice Hall. 544 p

Knipling EB, West SH, Haller WT (1970) Growth characteristics, yield potential, and nutritive content of water hyacinths. Proc Soil Crop Soc Florida 30:51-63

Law BE, Waring RH (1994) Remote sensing of leaf area index and radiation intercepted by understory vegetation. Ecol Appl 4:272-279

Lehmann A, Lachavanne JB (1997) Geographic information systems and remote sensing in aquatic botany. Aquat Bot 58:195-207

Madsen JD (1993a) Biomass techniques for monitoring and assessing control of aquatic vegetation. Lake Reserv Manage 7:141-154

Madsen JD (1993b) Growth and biomass allocation patterns during waterhyacinth mat development. J Aquat Plant Manage 31:134-137 
McVea C, Boyd CE (1975) Effects of waterhyacinth cover on water chemistry, phytoplankton, and fish in ponds. J Environ Qual 4: 375-378

Mutanga O, Skidmore AK (2004) Narrow band vegetation indices overcome the saturation problem in biomass estimation. Int J Remote Sens 25:3999-4014

[NASA] National Aeronautics and Space Administration (2008) Lansat user s handbook. http://landsathandbook.gsfc.nasa.gov. Accessed May 17,2012

Owens CS, Madsen JD (1995) Low temperature limits of waterhyacinth. J Aquat Plant Manage 33:63-68

Peñuelas J, Filella I, Gamon JA, Field C (1997) Assessing photosynthetic radiation-use efficiency of emergent aquatic vegetation from spectral reflectance. Aquat Bot 58:307-315

Peñuelas J, Gamon JA, Griffin KL, Field CB (1993) Assessing community type, plant biomass, pigment composition, and photosynthetic efficiency of aquatic vegetation from spectral reflectance. Remote Sens Environ 46:110-118

Pine RT, Anderson LWJ, Hung SSO (1989) Non-destructive estimation of aquatic macrophyte biomass. J Aquat Plant Manage 27:47-49

Robles W, Madsen JD, Wersal RM (2010) Detecting and predicting herbicide injury on waterhyacinth using remote sensing. Invasive Plant Sci Manage 3:440-450

Rouse JW, Hass RH, Schell JA, Deering DW (1973) Monitoring vegetation systems in the Great Plains with ERTS., page 20, in Proceedings of the 3rd ERTS Symposium. Washington, DC: NASA/ Goddard Space Flight Center

Rushing WN (1974) Waterhyacinth research in Puerto Rico. Hyacinth Contr J 12:48-52

Spencer DF, Liow P, Chan WK, Ksander GG, Getsinger KD (2006) Estimating Arundo donax shoot biomass. Aquat Bot 84:272-276

Thursby GB, Chintala MM, Stetson D, Wigand C, Champlin DM (2002) A rapid, non-destructive method for estimating aboveground biomass of salt marsh grasses. Wetlands 22:626-630

Todd SW, Hoffer RM, Milchunas DG (1998) Biomass estimation on grazed and ungrazed rangelands using spectral indices. Int J Remote Sens 19:427-438
Tucker CJ (1977) Asymptotic nature of grass canopy spectral reflectance. Appl Optics 16:1151-1156

Tucker CJ (1979) Red and photographic infrared linear combinations for monitoring vegetation. Remote Sens Environ 8:127-150

Tucker CJ, Fung IY, Keeling CD, Gammon RH (1986) Relationship between atmospheric $\mathrm{CO}_{2}$ variations and a satellite-derived vegetation index. Nature 319:195-199

Tucker CJ, Sellers PJ (1986) Satellite remote sensing of primary production. Int J Remote Sens 7:1395-1416

Tucker CJ, Vanpraet CL, Sharman MJ, Van Ittersum G (1985) Satellite remote sensing of total herbaceous biomass production in the Senegalese Sabel: 1980-1984. Remote Sens Environ 17:233-249

Underwood EC, Mulitsch MJ, Greenberg JA, Whiting ML, Ustin SL, Kefauver SC (2006) Mapping invasive aquatic vegetation in the Sacramento-San Joaquin Delta using hyperspectral imagery. Environ Monit Assess 121:47-64

[USGS] United States Geological Survey (2013a) Landsat 8. Fact Sheet 2013-3060. $4 \mathrm{p}$

[USGS] United States Geological Survey (2013b) Landsat-A global land-imaging mission. Fact Sheet 2012-3072. 4 p

Valta-Hulkkonen K, Kanninen A, Pellikka P (2004) Remote sensing and GIS for detecting changes in the aquatic vegetation of a rehabilitated lake. Int J Remote Sens 25:5745-5758

Vis C, Hudon C, Carignan R (2003) An evaluation of approaches used to determine the distribution and biomass of emergent and submerged aquatic macrophytes over large spatial scales. Aquat Bot $77: 187-201$

Xie Y, Sha Z, Yu M. (2008) Remote sensing imagery in vegetation mapping: a review. J Plant Ecol 1:9-23

Zhang, M., S. L. Ustin, E. Rejmankova, and E. W. Sanderson. 1997. Monitoring pacific coast salt marshes using remote sensing. Ecol Appl, 7:1039-105

Received May 2, 2014 and approved March 16, 2015. 